\title{
USE OF THE EGGSHELLS \\ IN REMOVING HEAVY METALS FROM WASTE WATER - THE PROCESS KINETICS AND EFFICIENCY
}

\author{
ZAGOSPODAROWANIE SKORUP JAJ DO USUWANIA METALI CIEŻ̇KICH \\ ZE ŚCIEKÓW - KINETYKA I SKUTECZNOŚĆ PROCESU
}

\begin{abstract}
Studies of the efficiency of $\mathrm{Ni}, \mathrm{Cu}$ and $\mathrm{Cd}$ cations removal from water solutions were carried out, with the use of clay limestone, hen eggshells from eggs for consumption and hen eggshells after hatching, which main element is calcium carbonate. Hen eggshells are a waste product, which can be used as a substitute of clay limestone in removing heavy metals from wet flue gas desulphurisation installation. Mixed solutions of $\mathrm{Ni}, \mathrm{Cu}$ and $\mathrm{Cd}$ were used in the research, with the composition similar to the waste water from wet flue gas desulphurisation installation: $\mathrm{Ni}\left(0.009-0.053 \mathrm{mmol} / \mathrm{dm}^{3}\right), \mathrm{Cu}\left(0.008-0.057 \mathrm{mmol} / \mathrm{dm}^{3}\right)$ and $\mathrm{Cd}\left(0.003-0.008 \mathrm{mmol} / \mathrm{dm}^{3}\right)$. The metals were determined by flame atomic absorption spectrophotometry (F-AAS). Kinetics of the process was analysed and equilibrium parameters were estimated, taking into consideration changes of the solutions $\mathrm{pH}$ during the process duration. It was demonstrated that the dominating mechanism of cations removal is their binding in hydroxides and carbonates. The studies demonstrated comparable characteristics of hen eggshells versus clay limestone, in the context of their application in removal of heavy metal cations from solutions.
\end{abstract}

Keywords: hen eggshells, clay limestone, heavy metals, industrial sewage treatment

\section{Introduction}

Hen eggshells, due to their chemical composition and structure, are a valuable raw material, which can be the source of calcium carbonate $\left(\mathrm{CaCO}_{3}\right.$ is over $94 \%$ of a shell mass), e.g. in paper industry as a filler and pigment for coating, in food industry as a hardener and food dye (E 170), in agriculture for fertiliser manufacturing, in metallurgy as a flux in ladle desulphurisation, in construction, chemical, cosmetics and pharmaceutical industries. The research has been carried out in recent years on the possibility to use eggshells as a catalyst in the processes of biodiesel production [1,2], lactose isomerisation [3], dimethyl carbonate synthesis [4] and as a sorbent in water treatment processes [5, 6], immobilisation of heavy metals in soils [7, 8], $\mathrm{CO}_{2}$ binding (removing) [9].

Studies on the use of eggshells in sewage treatment process have also been carried out [10-14]. The effectiveness of water solutions purification depends on a number of factors, among others $\mathrm{pH}$, concentration, sorbent particles size, dose and contact period,

\footnotetext{
${ }^{1}$ Institute of Technical Sciences, University of Opole, ul. R. Dmowskiego 7-9, 45-365 Opole, Poland, email: amak@uni.opole.pl
} 
competitive sorption of ions $[15,16]$. In this context, studies have been carried out aiming at increasing the process intensity by eggshells modification: thermal, e.g. calcination $[17,18]$, chemical $[19,20]$ and mechanical, e.g. grinding [21, 22].

The attempt to lower the process costs by using the mass-scale produced waste as sorbents, which are not activated by any additional process, is an important aspect [23].

In the context of eggshells use, industrial applications are still very few, at the current research stage. Therefore it is recommended to search for alternative methods of their use. The proposed method is to use this by-product as a substitute of clay limestone in the process of heavy metals removal from waste water in wet flue gas desulphurisation installations. Waste water from wet flue gas desulphurisation installations contain large quantities of heavy metals $(\mathrm{Cu}, \mathrm{Zn}, \mathrm{Cd}, \mathrm{Pb}, \mathrm{Ni}, \mathrm{Cr}, \mathrm{Hg})$, large concentration of chlorides, sulphates, nitrogen compounds, the presence of organic substances and mineral suspensions [24]. The treatment process involves using clay limestone, mainly to precipitate heavy metals in the form of hydroxides and carbonates, in slightly alkaline environment ( $\mathrm{pH} \mathrm{8-9).}$

The aim of the carried out studies was to compare the efficiency of removal of $\mathrm{Ni}, \mathrm{Cu}$ and $\mathrm{Cd}$ from water solutions, with the use of clay limestone, hen eggshells and hen eggshells after hatching, in the context of the possibility to use these materials to remove heavy metals from waste water in wet flue gas desulphurisation installations. Hen eggshells after hatching have different mass proportions of organic and non-organic substances, compared to the shells from eggs for consumption. The studies were carried out by measurements of the process kinetics and comparison of the efficiency of the prepared waste water treatment.

The hypothesis was accepted, that metal cations removal from solutions with the use of eggshells, similarly as with clay limestone, undergoes in consequence of chemical reactions, which lead to generation of sparingly soluble hydroxides and carbonates, which can be physically adsorbed on the shells' surface and not in consequence of a heterophasic ions exchange and chemical adsorption, as suggested by some authors.

\section{Materials and methods}

Clay limestone (WM), hen eggshells for consumption (SK) and hen eggshells after hatching (SW) have been used in the study.

\section{Characteristics of the analysed material}

Chemical composition and heat and thermophysical characteristics of eggshells are similar to widely used clay limestone. The compared materials have similar crystalline structure, however carbonates in eggshells have larger crystals [25]. Table 1 presents data on chemical composition of WM (own research) and SK [26].

Chemical composition of shells (SK) changes during incubation and their thickness is reduced [27]. Shells (SW) after 21 days of incubation contain approximately $15 \%$ less calcium and approximately $20 \%$ less magnesium [28]. Shells after hatching have more membranes under shell, which have good sorption characteristics with regard to metal cations $[22,29]$.

The indicated differences in chemical composition may influence the mechanism and efficiency of metal cations removal from water solutions. 
Comparison of clay limestone and hen eggshells

\begin{tabular}{|c|c|c|}
\hline Chemical compound & WM [\%] & SK [\%] \\
\hline $\mathrm{CaCO}_{3}$ & 97.20 & 94 \\
\hline $\mathrm{MgO}$ & 0.61 & - \\
\hline $\mathrm{Fe}_{2} \mathrm{O}_{3}$ & 0.38 & - \\
\hline $\mathrm{Al}_{2} \mathrm{O}_{3}$ & 0.26 & - \\
\hline $\mathrm{SiO}_{2}$ & 0.87 & - \\
\hline $\mathrm{Ca}_{3}\left(\mathrm{PO}_{4}\right)_{2}$ & - & 1 \\
\hline $\mathrm{MgCO}_{3}$ & - & 1 \\
\hline Organic compounds & - & 4 \\
\hline Other & 0.68 & - \\
\hline
\end{tabular}

\section{The research methodology}

WM samples sized $<90 \mu \mathrm{m}$, used in removal of heavy metals from waste water in wet flue gas desulphurisation installations, were used in the studies. Hen eggshells were obtained from a poultry hatchery. SK shells were obtained from unfertilised eggs and SW shells were a by-product after chicken hatching. Shells were rinsed in deionised water, keeping under shell membranes; next they were fragmented (to approximately $50 \mathrm{~mm}$ diameter) and dried to dry mass at $105^{\circ} \mathrm{C}$. Next they were ground in a knife mill and sieved out on a $100 \mu \mathrm{m}$ mesh sieve. The fraction $<100 \mu \mathrm{m}$ was used in the research.

The research was carried out with the use of $200 \mathrm{~cm}^{3}$ solutions, in which $1 \mathrm{~g}$ of WM, SK or SW was placed. The process of metals removal, with intense stirring (500 rotations/min), was carried out for 3 hours at room temperature. The solution samples (approximately $1 \mathrm{~cm}^{3}$ ), for determining the process kinetics parameters, were taken every 30 minutes. The initial solution $\mathrm{pH}$ was within the range 4.6-5.4. Metals in the solution were determined by flame atomic absorption spectrophotometry (F-AAS).

\section{Quality and quality assurance}

The absorbing atomic spectroscope iCE 3000 made by Thermo Electron Corporation, USA, was used to determine heavy metals concentrations in the solutions. The $\mathrm{pH}$ of solutions were immersed was measured with a CP551 pH-meter from Elmetron Sp.j. from Zabrze (PL). The absolute error of readings was $\triangle \mathrm{pH}=0.02$. MERCK reagents were used to prepare the solutions.

Uncertainty of determination of the analysed metals by AAS method did not exceed $10 \%$. Limits of determination $(I Q L)$ for $\mathrm{Ni}, \mathrm{Cu}$ and $\mathrm{Cd}$ were respectively $\left[\mathrm{mg} / \mathrm{dm}^{3}\right]: 0.024$, 0.015 and 0.010 .

Detailed data for the equipment, together with an evaluation and quality assurance, were published in [30].

\section{Results interpretation method}

The pseudo-second-order reaction model [31,32] was applied to describe kinetics of metal cations removal, based on the relation:

$$
\frac{t}{q_{M(t)}}=\frac{1}{k \prime \cdot\left(q_{M(e q)}\right)^{2}}+\frac{1}{q_{M(e q)}} \cdot t
$$


where: $k "$ - constant speed of pseudo-second-order reaction, $q_{M(t)}$ - metal concentration in bound form after time $t, q_{M(e q)}$ - metal concentration in bound form in equilibrium.

Concentration of metals in bound form, related to the mass of $1 \mathrm{~g}$ of WN, SK or SW, was calculated on the basis of the results of initial and instantaneous concentrations measurements in the solution. Concentrations were expressed in $\mathrm{mmol} / \mathrm{g}$ for comparison, in the kinetics description.

Concentrations of $\mathrm{M}^{+2}$ metal cations, which were in equilibrium with $\mathrm{M}(\mathrm{OH})_{2}$, were determined on the basis of the relation:

$$
\mathrm{pH}_{\text {prec. }}=z^{-1} \cdot\left(14 \cdot z-\log C_{M}^{+z}{ }_{(e q)}-\mathrm{p} K_{s p}\right)
$$

where: $\mathrm{pH}_{\text {prec. }}$ - the $\mathrm{pH}$ value, above which hydroxides precipitate, $z$ - cation valence, $C_{M}{ }^{+z}(e q)$ - copper cations concentration in the solution [mol dm$\left.{ }^{-3}\right], K_{s p}$ - solubility product constants $\left(\mathrm{p} K_{s p}=-\log K_{s p}\right)$, for nickel, copper and cadmium hydroxide, values of $\mathrm{p} K_{s p}$ are, respectively: $15.3,19.3$ and 14.1 .

The loss of metal cations (removal efficiency), $U$, from the solution was calculated on the basis of the relation:

$$
U=\frac{C_{0}-C_{1}}{C_{0}} \cdot 100 \%
$$

where: $C_{0}$ and $C_{1}$ - initial and final concentrations of metal cations in the solution.

\section{Results and discussion}

The studies of the $\mathrm{Ni}, \mathrm{Cu}$ and $\mathrm{Cd}$ removal with the use of WM, SK and SW were carried out in the solutions with metal concentrations within the range determined in waste water in wet flue gas desulphurisation installations [24]. Table 2 presents the initial composition of the solutions.

Initial composition of the solutions used in the research $\left[\mathrm{mmol} / \mathrm{dm}^{3}\right]$

Table 2

\begin{tabular}{|c|c|c|c|}
\hline Metal & Solution I & Solution II & Solution III \\
\hline $\mathrm{Ni}$ & 0.0090 & 0.0351 & 0.0532 \\
\hline $\mathrm{Cu}$ & 0.0069 & 0.0381 & 0.0674 \\
\hline $\mathrm{Cd}$ & 0.0033 & 0.0063 & 0.0078 \\
\hline
\end{tabular}

Taking $\mathrm{pH}$ measurements before and after the process was an important parameter, indicating the process of precipitation of hydroxides of the studied metals (relation (2)). The results are presented in Table 3.

Initial (0) and final (1) $\mathrm{pH}$ values of the solutions

\begin{tabular}{|c|c|c|c|c|c|c|}
\hline \multirow{2}{*}{ Solution } & \multicolumn{3}{|c|}{$\mathbf{p H}_{\mathbf{0}}$} & \multicolumn{3}{c|}{$\mathbf{p H}_{\mathbf{1}}$} \\
\cline { 2 - 7 } & $\mathbf{W M}$ & SK & SW & WM & SK & SW \\
\hline I & 4.77 & 4.77 & 4.78 & 8.90 & 8.82 & 8.81 \\
\hline II & 4.60 & 4.59 & 4.59 & 8.33 & 8.52 & 8.38 \\
\hline III & 5.47 & 5.46 & 5.47 & 7.87 & 8.07 & 8.09 \\
\hline
\end{tabular}




\section{Kinetics of the removal processes}

The objective of assessment of heavy metals removal process kinetics parameters was to point out similarities and differences of the process, using WM, SK and SW. Figure 1 presents two different examples, indicating the influence of heavy metals concentration in a solution on the kinetics of the $\mathrm{Ni}$ and $\mathrm{Cd}$ removal process.

a)

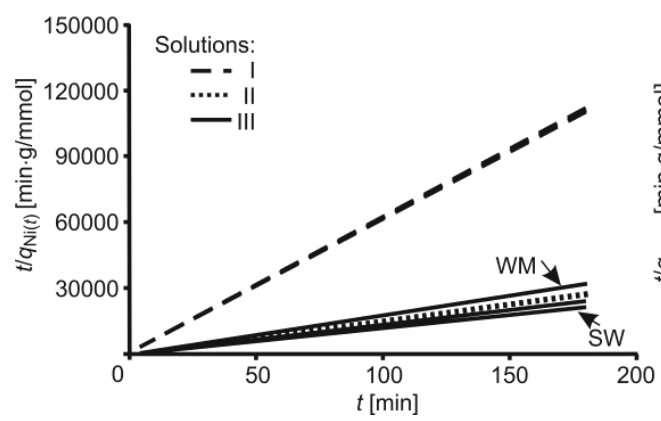

b)

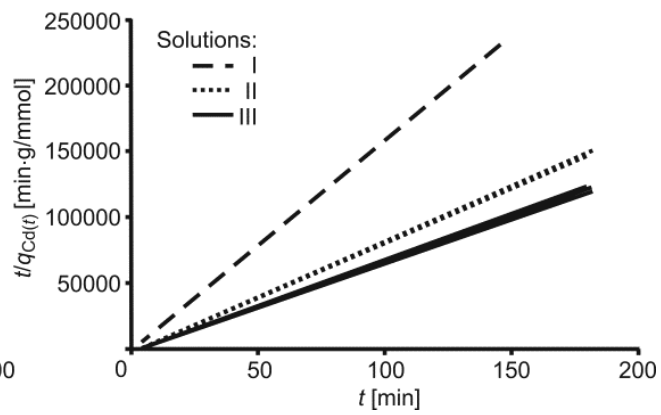

Fig. 1. Kinetics of a) Ni and b) Cd removal from I-III solutions with the use of WM, SK and SW

The results presented in the graph in Figure 1a indicate similarities of the removal parameters, in the range of higher initial concentrations of nickel cations, and slightly better parameters with the use of SW versus WM, with the highest initial concentrations (Solution III). In relation to cadmium (Fig. 1b), similarly as in the case of copper, no differences in removal kinetics with WM, SK and SW were recorded (directional coefficients of the straight lines determined on the basis of relation 1 do not depend on the source of $\mathrm{CaCO}_{3}$ origin, but only on the initial concentration of metals in the solution).

Table 4 presents data related to the values $q_{M(e q)}[\mathrm{mmol} / \mathrm{g}]$, determined on the basis of relation (1), indicating the concentration of metals in bound form in equilibrium, calculated values of metal cations concentrations in solution $c_{M(e q)}\left[\mathrm{mmol} / \mathrm{dm}^{3}\right]$, in equilibrium and, determined on the basis of relation (2), theoretical values of metal cations concentration values in solution $C_{M(e q)}\left[\mathrm{mmol} / \mathrm{dm}^{3}\right]$, being in equilibrium with hydroxide suspension. In this case, equilibrium referred to the recorded average final $\mathrm{pH}$ of the solution (Table 3). The values $q_{M(e q)}$ and $c_{M(e q)}$ presented in the table refer to the average values for WM, SK and SW and are different for initial concentrations of metals in the solutions I-III (Table 2).

Values $q_{M(e q)}, c_{M(e q)}$ calculated on the basis of relation (1) and theoretical values of metal cations concentrations in a solution in equilibrium $C_{M(e q)}$ determined on the basis of relation (2)

\begin{tabular}{|c|c|c|c|c|c|c|c|c|c|}
\hline \multirow[b]{2}{*}{ Solution } & \multicolumn{3}{|c|}{$\mathbf{N i}$} & \multicolumn{3}{|c|}{$\mathbf{C u}$} & \multicolumn{3}{|c|}{ Cd } \\
\hline & $\begin{array}{c}q_{M(e q)} \\
{[\mathbf{m m o l} /} \\
\mathbf{g}]\end{array}$ & $\begin{array}{c}c_{M(e q)} \\
{\left[\mathrm{mmol}^{3} /\right.} \\
\left.\mathbf{d m}^{3}\right]\end{array}$ & $\begin{array}{c}C_{M(e q)} \\
{[\mathrm{mmol} /} \\
\left.\mathrm{dm}^{3}\right]\end{array}$ & $\begin{array}{c}q_{M(e q)} \\
{[\mathbf{m m o l} /} \\
\mathbf{g}]\end{array}$ & $\begin{array}{c}c_{M(e q)} \\
{\left[\mathrm{mmol}^{2} /\right.} \\
\left.\mathbf{d m}^{3}\right]\end{array}$ & $\begin{array}{c}C_{M(e q)} \\
{[\mathrm{mmol} /} \\
\left.\mathrm{dm}^{3}\right]\end{array}$ & $\begin{array}{c}q_{M(e q)} \\
{[\mathbf{m m o l} /} \\
\mathbf{g}]\end{array}$ & $\begin{array}{c}c_{M(e q)} \\
{\left[\mathrm{mmol}^{3} /\right.} \\
\left.\mathbf{d m}^{3}\right]\end{array}$ & $\begin{array}{c}C_{M(e q)} \\
{[\mathrm{mmol} /} \\
\left.\mathrm{dm}^{3}\right]\end{array}$ \\
\hline I & $1.7 \cdot 10^{-3}$ & $1.5 \cdot 10^{-3}$ & $1.0 \cdot 10^{-2}$ & $\frac{81}{1.4 \cdot 10^{-3}}$ & $9.4 \cdot 10^{-6}$ & $1.1 \cdot 10^{-6}$ & $6.0 \cdot 10^{-4}$ & $1.2 \cdot 10^{-4}$ & $1.7 \cdot 10^{-1}$ \\
\hline II & $2.6 \cdot 10^{-3}$ & $6.5 \cdot 10^{-3}$ & $1.7 \cdot 10^{-2}$ & $7.6 \cdot 10^{-3}$ & $5.7 \cdot 10^{-6}$ & $7.6 \cdot 10^{-6}$ & $1.1 \cdot 10^{-3}$ & $9.4 \cdot 10^{-4}$ & $1.2 \cdot 10^{0}$ \\
\hline III & $6.6 \cdot 10^{-3}$ & $2.0 \cdot 10^{-2}$ & $4.8 \cdot 10^{-1}$ & $1.4 \cdot 10^{-2}$ & $4.6 \cdot 10^{-5}$ & $4.8 \cdot 10^{-5}$ & $1.3 \cdot 10^{-3}$ & $1.2 \cdot 10^{-3}$ & $7.6 \cdot 10^{0}$ \\
\hline
\end{tabular}


The results presented in the table are estimates. The values of concentrations $c_{M(e q)}$, determined from the pseudo-second-order equation (relation (1)) and the values $C_{M(e q)}$, determined from the relation (2) are of considerable importance. Similar values $c_{M(e q)}$ and $C_{M(e q)}$ with regard to copper may indicate that the final $\mathrm{pH}$ of the solution has the main influence on equilibrium. Increased $\mathrm{pH}$ value is a result of calcium carbonate dissociation: $\mathrm{CaCO}_{3} \leftrightarrows \mathrm{Ca}^{2+}+\mathrm{CO}_{3}{ }^{2-}$, next, in hydrolysis: $\mathrm{CO}_{3}{ }^{2-}+\mathrm{H}_{2} \mathrm{O} \leftrightarrows \mathrm{HCO}_{3}{ }^{-}+\mathrm{OH}^{-}$. In consequence, the equilibrium is achieved: $\mathrm{Cu}^{2+}+2 \mathrm{OH}^{-} \leftrightarrows \mathrm{Cu}(\mathrm{OH})_{2}$. Much lower values of $c_{M(e q)}$ in comparison to $C_{M(e q)}$, in particular for $\mathrm{Cd}$, may indicate a considerable influence on generation of insoluble carbonates during the process of removal of these metals cations from solutions. The values $K_{s p}$ for $\mathrm{NiCO}_{3}$ and $\mathrm{Ni}(\mathrm{OH})_{2}$ are on the level $10^{-7}$ and $10^{-16}$, for $\mathrm{CuCO}_{3}$ and $\mathrm{Cu}(\mathrm{OH})_{2}$ are on the level $10^{-10}$ and $10^{-20}$, and for $\mathrm{CdCO}_{3}$ and $\mathrm{Cd}(\mathrm{OH})_{2}$ are on the level $10^{-12}$ and $10^{-15}$. These values indicate relatively high, in comparison to the quoted examples, solubility of nickel carbonate and relatively small differences of the values $K_{s p}$ for $\mathrm{CdCO}_{3}$ and $\mathrm{Cd}(\mathrm{OH})_{2}$. The difference of $K_{s p}$ values may explain the results of previously discussed studies, presented in [33]. The initial, mol concentration of metal cations is also of importance.

These comparisons confirm and supplement the result of below presented studies on effectiveness of the studied metal cations removal from solutions.

\section{Effectiveness of metals removal}

Figure 2-4 presents a comparison of effectiveness of $U$ removal (relation (3)) of the studied heavy metals from solutions with the use of clay limestone (WM), hen eggshells for consumption (SK) and eggshells after hatching (SW).

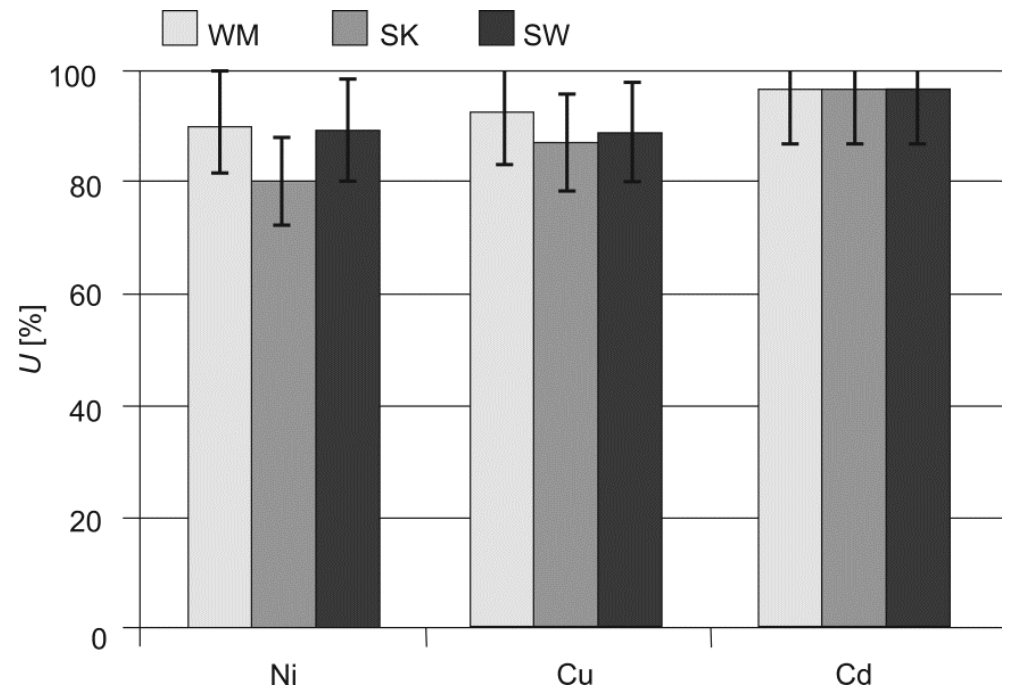

Fig. 2. Effectiveness of nickel, copper and cadmium cations removal from Solution I (Table 2) with the use of WM, SK and SW

The concentrations of $\mathrm{Ni}, \mathrm{Cu}$ and $\mathrm{Cd}$ in Solution I did not exceed $0.01 \mathrm{mmol} / \mathrm{dm}^{3}$. In this range of concentrations, WM demonstrated the highest, over $90 \%$ effectiveness of 
removal of all studied metals. SK and SW provided slightly lower results (80\% and more), however, as mentioned above, uncertainty of determination of the studied metals is $10 \%$, which is illustrated by error bars. It should be assumed that, due to the content of organic substances in eggshells, the progress of the process: $\mathrm{CaCO}_{3} \leftrightarrows \mathrm{Ca}^{2+}+\mathrm{CO}_{3}{ }^{2-}$ may be less effective which, in turn, influences the hydrolysis process and generation of insoluble hydroxides and carbonates of the studied heavy metals.

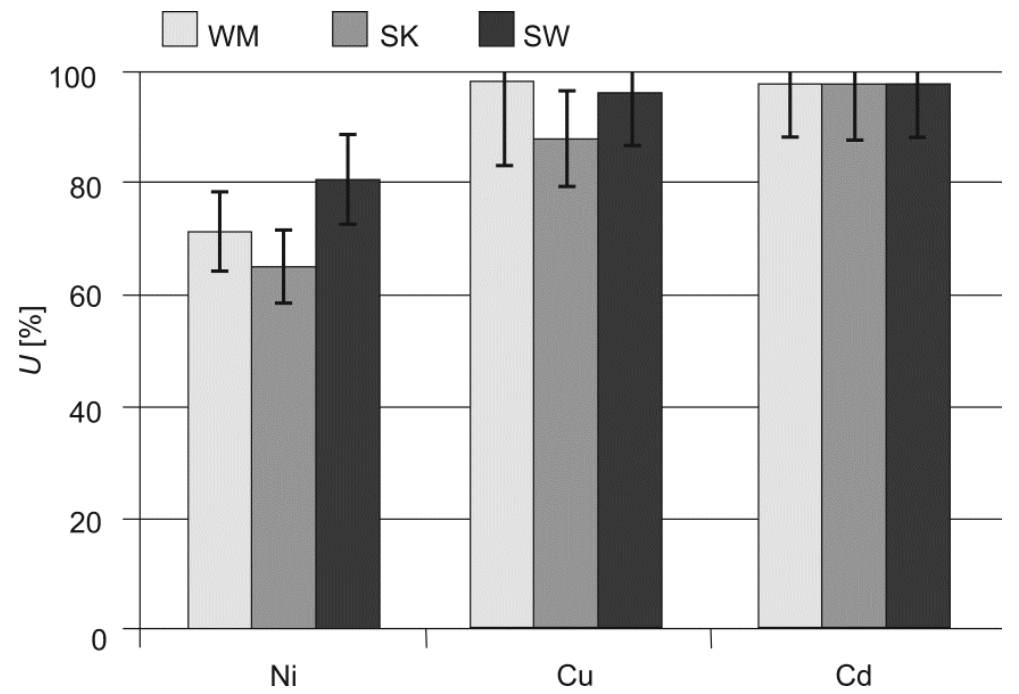

Fig. 3. Effectiveness of nickel, copper and cadmium cations removal from Solution II (Table 2) with the use of WM, SK and SW

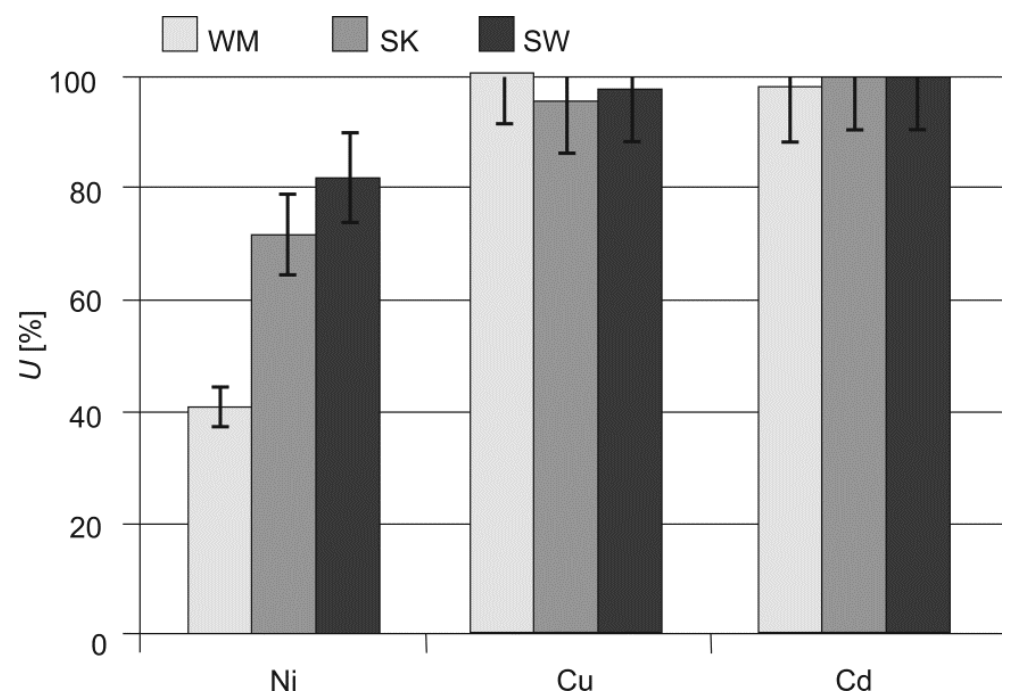

Fig. 4. Effectiveness of nickel, copper and cadmium cations removal from Solution III (Table 2) with the use of WM, SK and SW 
The results presented in Figure 2 indicate that with metal concentrations not exceeding $0.04 \mathrm{mmol} / \mathrm{dm}^{3}$, nickel cations removal effectiveness decreases by the values higher than the determined values of measurement uncertainty.

The comparison of the data presented in Figures 2-4 indicates that with increased initial concentrations of $\mathrm{Ni}, \mathrm{Cu}$ and $\mathrm{Cd}$ cations, the effectiveness of $\mathrm{Ni}$ cations removal decreases, in comparison to other metal cations. The differences in effectiveness of nickel removal by WM, SK and SW from Solution III were also demonstrated. Much lower effectiveness of Ni removal, in comparison to SK (approx. $70 \%$ ) and SW (approx. $80 \%$ ), was registered in the case of using clay limestone (approx. $40 \%$ ).

The data from literature, related to the use of hen eggshells use in removing heavy metal cations from solutions, confirm effectiveness of the method. It was demonstrated that, among others, at initial concentrations of the cations: $\mathrm{Cu}, \mathrm{Cd}$ and $\mathrm{Pb}$ in a solution of $10 \mathrm{mg} / \mathrm{dm}^{3}$ (pH approx. 5.5), removal effectiveness was close to $100 \%$ and was decreasing with the increase of initial concentration of metal cations in the solution, which is in accordance with the presented study results. For the initial metal cations concentrations $c_{\mathrm{Cu}}=60 \mathrm{mg} / \mathrm{dm}^{3}\left(0.94 \mathrm{mmol} / \mathrm{dm}^{3}\right), \quad c_{\mathrm{Cd}}=60 \mathrm{mg} / \mathrm{dm}^{3}\left(0.53 \mathrm{mmol} / \mathrm{dm}^{3}\right)$ and $c_{\mathrm{Pb}}=150 \mathrm{mg} / \mathrm{dm}^{3}\left(0.72 \mathrm{mmol} / \mathrm{dm}^{3}\right)$, the removal effectiveness decreased to approximately 85,21 and $79 \%$, respectively [33]. Detailed studies on the effectiveness of $\mathrm{Ni}$ and $\mathrm{Ag}$ cations removal from solutions, with the use of eggshells divided by shells with organic membrane, shells without membranes and membranes alone, demonstrated that the removal effectiveness decreases along with the increase of the initial concentration of metal cations in the solution [34]. Moreover, it was demonstrated that removal effectiveness depends on the contact time, the relation $V / m$, where: $V$ - a solution volume, $m$ - shells mass, a solution temperature and $\mathrm{pH}$. It was demonstrated that under shell membranes have very good sorption characteristics, which improves effectiveness of metal cations removal.

However, it should be emphasised that comparing the values $U$ (relation (3)), which are relative, presents a view on the treatment effects, but it does not indicate the process effectiveness in the absolute sense. For example, for the solutions I-III, the effectiveness of copper removal by SK was approx. $90 \%$, whereas, taking into consideration the initial concentrations of copper in the solutions (Table 2), the absolute changes of copper cations concentrations decreased for the solutions I-III by, respectively: $0.0063,0.0346$ and $0.0613 \mathrm{~mol} / \mathrm{dm}^{3}$.

Relatively highest effectiveness of Ni removal by SW (Figs. 3 and 4) may be justified by, as mentioned before, the largest use of under shell membranes with very good sorption characteristics [34]. The process of hydroxides generation during the process of the studied metal cations removal is confirmed by the solutions $\mathrm{pH}$ measurements results. Regardless of the calcium carbonate source (WM, SK or SW), the final $\mathrm{pH}$ values of solutions were decreasing, along with the increase of initial metals concentrations in the solution, which also indicates a chemical reaction, which generates insoluble hydroxides.

\section{Conclusions}

The carried out research demonstrated that hen eggshells can be successfully used as a substitute of clay limestone in removal heavy metals from waste water in wet flue gas desulphurisation installations. This is of considerable importance, as the shells have been treated as a waste product so far. It has also been demonstrated that the dominating mechanism of metal cations removal is their precipitation in the form of hydroxides and 
carbonates, however, the process of removal with the use of shells may also undergo as a result of ions exchange on the organic compounds of the shells, particularly in under shell membranes.

\section{References}

[1] Tan YH, Abdullah MO, Nolasco-Hipolito C. The potential of waste cooking oil-based biodiesel using heterogeneous catalyst derived from various calcined eggshells coupled with an emulsification technique: A review on the emission reduction and engine performance. Renew Sust Energy Rev. 2015;47:589-603. DOI: 10.1016/j.rser.2015.03.048.

[2] Shan R, Zhao Ch, Lv P, Yuan H, Yao J. Catalytic applications of calcium rich waste materials for biodiesel: Current state and perspectives. Energy Convers Manage. 2016;127:273-283. DOI: 10.1016/j.enconman.2016.09.018.

[3] Nooshkam M, Madadlou A. Maillard conjugation of lactulose with potentially bioactive peptides. Food Chem. 2016;192:831-836. DOI: 10.1016/j.foodchem.2015.07.094.

[4] Gao Y, Xu Ch. Synthesis of dimethyl carbonate over waste eggshell catalyst. Catalysis Today. 2012;190:107-111. DOI: 10.1016/j.cattod.2011.12.004

[5] Pavlovič DM, Ćurkowič L, Macan J, Žižek K. Eggshell as a new biosorbent for the removal of pharmaceuticals from aqueous solutions. Clean - Soil, Air, Water. 2017;45:1700082. DOI: 10.1002/clen.201700082.

[6] Kuśmierek K, Idźkiewicz P, Świątkowski A, Dąbek L. Adsorptive removal of pentachlorophenol from aqenos solutions using powdered eggshell. Archives Environ Protect. 2017;43(3):10-16. DOI: 10.1515/aep-2017-0029.

[7] Shaheen SM, Rinklebe J. Phytoextraction of potentially toxic elements by Indian mustard, rapeseed, and sunflower from a contaminated riparian soil. Environ Geochem Health. 2015;37:953-967. DOI: 10.1007/s10653-015-9718-8.

[8] Soares MAR, Quina MJ, Quinta-Ferreira RM. Immobilisation of lead and zinc in contaminated soil using compost derived from industrial eggshell. J Environ Manage. 2015;164:137-145. DOI: 10.1016/j.jenvman.2015.08.042.

[9] Quina MJ, Soares MAR, Quinta-Ferreira R. Applications of industrial eggshell as a valuable anthropogenic resource. Resour Conservat Recyc. 2017;123:176-186. DOI: 10.1016/j.resconrec.2016.09.027.

[10] Ummartyotin S, Pechyen C. Strategies for development and implementation of bio-based materials as effective renewable resources of energy: A comprehensive review on adsorbent technology. Renew Sust Energy Rev. 2016;62:654-664, DOI: 10.1016/j.rser.2016.04.066.

[11] Laca A, Laca A, Díaz M. Eggshell waste as catalyst: A review. J Environ Manage. 2017;197:351-359. DOI: 10.1016/j.jenvman.2017.03.088.

[12] Bhaumik R, Mondal NK, Das B, Roy P, Pal KC, Das C, et al. Eggshell powder as an adsorbent for removal of fluoride from aqueous solution: Equilibrium. Kinetic Thermodynamic Studies, E-J Chem. 2012;9(3):1457-1480. DOI: 10.1155/2012/790401.

[13] Nahar K, Chowdhury MdAK, Chowdhury MdAH, Rahman A, Mohiuddin KM. Heavy metals in handloom-dyeing effluents and their biosorption by agricultural byproducts. Environ Sci Pollut Res. 2018;25:7954-7967. DOI: 10.1007/s11356-017-1166-9.

[14] Zhang T, Tu Z, Lu G, Duan X, Yi X, Guo Ch, Dang Z. Removal of heavy metals from acid mine drainage using chicken eggshells in column mode. J Environ Manage. 2017;188:1-8. DOI: 10.1016/j.jenvman.2016.11.076.

[15] Kłos A. Determination of sorption properties of heavy metals in various biosorbents. Ecol Chem Eng S. 2018;25(2):201-216. DOI: 10.1515/eces-2018-0013.

[16] Zinicovscaia I, Safonov A, Tregubova V, Ilin V, Cepoi L, Chiriac T, et al. Uptake of metals from single and multi-component systems by Spirulina platensis biomass. Ecol Chem Eng S. 2016;23(3):401-412. DOI: 10.1515/eces-2016-0028.

[17] Park HJ, Jeong SW, Yang JK, Kim BG, Lee SM. Removal of heavy metals using waste eggshell. J Environ Sci. 2007;19:1436-1441. DOI: 10.1016/S1001-0742(07)60234-4.

[18] Eletta OAA, Ajayi OA, Ogunleye OO, Akpan IC. Adsorption of cyanide from aquenos solution using calcined eggshells: Equilibrium and optimisation studies. J Environ Chem Eng. 2016;4:1367-1375. DOI: 10.1016/j.jece.2016.01.020.

[19] Liao D, Zheng W, Li X, Yang Q, Yue X, Guo L, et al. Removal of lead(II) from aqueous solutions using carbonate hydroxyapatite extracted from eggshell waste. J Hazard Mater. 2010;177:126-130. DOI: 10.1016/j.hazmat.2009.12.005. 
[20] Ren J, Bopape MF, Setshedi K, Kitinya JO, Onyango MS. Sorption of $\mathrm{Pb}$ (II) and $\mathrm{Cu}(\mathrm{II})$ by low-cost magnetic eggshells- $\mathrm{Fe}_{3} \mathrm{O}_{4}$ powder. Chem Indust Chem Eng Quartel. 2012;18(2):221-231. DOI: 10.2298/CICEQ110919063R.

[21] Baláž M, Bujňákova Z, Baláž P, Zorkovská A, Danková Z, Briančin J. Adsorption of cadmium(II) on waste biomaterial. J Colloid Interface Sci. 2015;454:121-133. DOI: 10.1016/j.jcis.2015.03.046.

[22] Baláž M, Ficeriová J, Briančin J. Influence of milling on the adsorption ability of eggshell waste. Chemosphere. 2016;146:458-471. DOI: 10.1016/j.chemosphere.2015.12.002.

[23] Yildiz S. Kinetic and isotherm analysis of $\mathrm{Cu}$ (II) adsorption onto almond shell (Prunus dulcis). Ecol Chem Eng S. 2017;24(1):87-106. DOI: 10.1515/eces-2017-0007.

[24] Bogacki J, Marcinowski P, Majewski M, Zawadzki J, Sivakumar S. Alternative approach to current EU BAT recommendation for coal-fired power plant flue gas desulfurization wastewater treatment. Processes. 2018;6(11):229. DOI: 10.3390/pr6110229.

[25] Murakami FS, Rodrigues PO, Campos C.MT, Silva MAS. Physicochemical study of $\mathrm{CaCO}_{3}$ from egg shells. Ciênc Tecnol Aliment Campinas. 2007;27(3):658-662. DOI: 10.1590/S0101-20612007000300035.

[26] Baláž M. Eggshell membrane biomaterial as a platform for applications in materials science. Acta Biomater. 2014;10:3827-3843. DOI: 10.1016/j.actbio.2014.03.020.

[27] Chien YC, Hincke MT, McKee MD. Ultrastructure of avian eggshell during resorption following egg fertilization. J Structur Biol. 2009;168:527-538. DOI: 10.1016/j.jsb.2009.07.005.

[28] Szeleszczuk Ł, Kuras M, Pisklak DM, Wawer I. Analysis of the changes in elemental composition of the chicken eggshell during the incubation period. J Animal Plant Sci. 2016;26(3):583-587. www.thejaps.org.pk/docs/v-26-03/03.pdf.

[29] Tsai WT, Yang JM, Lai CW, Cheng YH, Lin CC, Yeh CW. Characterization and adsorption properties of eggshells and eggshell membrane. Bioresour Technol. 2006;97:488-493. DOI: 10.1016/j.biortech.2005.02.050.

[30] Kłos A, Bochenek Z, Bjerke JW, Zagajewski B, Ziółkowski D, Ziembik Z, et al. The use of mosses in biomonitoring of the selected areas in Poland and Spitsbergen in the years from 1975 to 2014. Ecol Chem Eng S. 2015;22(2):201-218. DOI: 10.1515/eces-2015-0011.

[31] Ho YS, McKay G. Pseudo-second order model for sorption process. Process Biochem. 1999;34:451-465. DOI: 10.1016/S0032-9592(98)00112-5.

[32] Ho YS. Review of second-order models for adsorption systems. J. Hazard. Mater. 2006;136:681-689. DOI: 10.1016/j.jhazmat.2005.12.043.

[33] Ahmad M, Usman ARA, Lee SS, Kim SCh, Joo JH, Yang JE, et al. Eggshell and coral wastes as low cost sorbents for the removal of $\mathrm{Pb}^{2+}, \mathrm{Cd}^{2+}$ and $\mathrm{Cu}^{2+}$ from aqueous solutions. $\mathrm{J}$ Indust Eng Chem. 2012;18:198-204. DOI: 10.1016/j.jiec.2011.11.013.

[34] Ho JH, Yeh YN, Wang HW, Khoo S, Chen YH, Chow ChF. Removal of nickel and silver ions using eggshells with membrane, eggshell membrane, and eggshells. Food Sci Technol Res. 2014;20(2):337-343. DOI: $10.3136 /$ fstr.20.337. 